\title{
USING THE STRUCTURAL FAULT-TOLERANCE INDEX IN PROJECT DESIGNING
}

Introduction. Calculation of reliability as an object's complex characteristic represents the procedure of setting the appropriate indicators using methods based on their definition by reference data about the object elements' and the analog objects' reliability, data on material properties, and other data that we can get at the time of calculation. Data absence or inability to obtain such information should not cause refusal to assess the system reliability at any stage of its life cycle [1]. Providing respective professionals with the necessary information is quite time-consuming process as well as the accumulation of relevant statistical data, because the investigated object structure can be complicated, its components' list can vary and enlarge and to address issues related to reliability parameters' assessment required is the mathematical, software and information support.

In such a case, a specialist developing the technical object's reliability issues identifies the components necessary to calculate, basing on his own experience and the final result (obtained quantitative characteristics) depends only on his experience available and the correctness of methods and models applied [2]. Especially sharply the expert assessment possibility reduces when developing new, unique equipment because of lack for experts with this equipment operated experience meanwhile of that the technical, economic and environmental responsibility to take appropriate technical and technological decisions in today's realities may be too large.

Literature review. Modern technical facilities represent complex systems consisting of a large number of mutually interacting heterogeneous elements, which number may reach tens of thousands. However, the requirements for quality and efficiency of technical objects operation are becoming more strict because the failure of any object (part of the system) can lead to significant financial losses due to insufficient production volumes, technological process rhythm interruptions, loss of raw materials, need for repairs and more.

Solving the reliable operation problems relies upon implementing a systematic approach to ensure the reliability at all stages of the object's life cycle. The use of a common information space that

DOI 10.15276/opu.2.44.2014.24

(C) O.S. Savelyeva, O.M. Krasnozhon, O.U. Lebedeva, 2014

КОМП’ЮТЕРНІ Й ІНФОРМАЦЙНІ МЕРЕЖІ І СИСТЕМИ. АВТОМАТИЗАЦІЯ ВИРОБНИЦТВА 
satisfies CALS-technologies requirements, setting of optimal design, planning and maintenance tasks, application and development of appropriate mathematical tools make it possible to describe the technology creation and technical systems' operation throughout their life cycle [3, 4]. However, in all cases we must take into account the lack of the necessary simple and affordable software and mathematical apparatus, as the suggested new approaches to reliability parameters evaluation issues are oriented onto the system life cycle individual stages and do not take into account the mutual influence of design and operation phases tasks $[2,5]$. In addition, they require significant time and financial costs for obtaining necessary information, that effect being not acceptable neither for contemporary design nor a modern management as dramatically narrows the ability to analyze options for designs, manufacturing techniques, diagnostics and modes of operation of complex systems in real time [2].

Aim of the Research. This study is aimed onto improving the efficiency of design process and maintaining the decision-making at the design stage by selecting the technical objects' structure on the basis of the elaborated structural fault tolerance assessment method.

Main Body. The complex systems simulation allows exploring the specifics of their operation under different conditions when incompleteness and heterogeneity of their components reliability background information. Choosing the complex system right model structure not only provides the best selection of equipment, but also gives possibility to minimize further costs, such as equipment purchase, fault system repair or guaranteeing the system faultless within the required period of time.

For systems with loaded redundant design the development process is associated with a large number of discrete selection among components of various types regarding their reliability or weight in the overall system's fault tolerance. Optimizing such systems with network structure, including several redundant subsystems $k$-of- $n$ represents a $N P$-complex problem [6].

If the system reliability is determined

$$
\begin{aligned}
& \prod_{i=1}^{s} R_{i}\left(x_{i} \mid k_{i}\right) \geq R, \\
& \sum_{j=1}^{m_{i}} x_{i j} \geq k_{i}, \quad \forall i,
\end{aligned}
$$

where $R_{i}$ - reliability of $i^{\text {th }}$ subsystem;

$R$ - reliability value limitation;

$X_{i}=\left(x_{i 1}, x_{i 2}, \ldots, x_{i m_{i}}\right), \quad n_{i}=\sum_{j=1}^{m_{i}} x_{i j} ;$

$x_{i j}$ - number of $j$-s components used at $i^{\text {th }}$ subsystem, $x_{i j} \in(0,1,2, \ldots)$;

$k_{i}$ - number of components connected in parallel at every subsystem $n_{i}$,

$m_{i}$ - number of functionally similar components at every subsystem $i$,

when the upper limit for $n$ not defined, the number of possible structural configurations $N$ is also unlimited. Provided we shall set such a limit $\left(n_{\max }\right)$, as a result there arises a possibility to determine the total number of system's configuration (elementary components set) variances considering every subsystem elementary components selection as an allocation problem. The generalized number of system structure unique variances

$$
N=\prod_{i=1}^{s}\left[\left(\begin{array}{c}
m_{i}+n_{\max } \\
m_{i}
\end{array}\right)-\left(\begin{array}{c}
m_{i}+k_{i}-1 \\
m_{i}
\end{array}\right)\right] .
$$

E.g. for $s=6, m_{i}=10$ and $n_{\max }=8$ possible are $6,9 \times 10^{27}$ various variances of system structure. So, the direct possibilities enumerative search can take too much time.

The research [7] suggests using the neuron networks to evaluate the faultless operation probability for separate elements as well as for complex system subsystems, at the condition that overall system's structure corresponds to some of the known neuron networks' (NN) types. The NN approach advantage is that they are efficient enough for simulating non-linear and statistically significant interactions. And the disadvantage consists in the necessity to train and in only approximate estimation of the system reliable operation probabilities. 
The structures' reliability can be preliminary assessed by the value of structural resiliency coefficient $C_{S R}$ [8]. Such index choice represents a difficult and controversial task as in general, the fault tolerance is a function of not only the project or management solutions variance, but of the facility future operation conditions, often unpredictable. Taking into account that the faultless operation $P(n)$ probability set values' dissipation power depends on the number of elements in the system $N$ and the number of faulty elements, $n$, to evaluate complex system structural resiliency considering the simulated object's specific situations in the diagnosis, design and operation the user should select from among several options for its calculation (see Table).

System structural reliability assessment parameters

\begin{tabular}{c|c|c|c}
\hline № & Identification & Formula & Applicability domain \\
\hline 1 & Total & $C_{S R \text { total }}=\sum_{i=0}^{N} P_{i}$ & $\begin{array}{c}\text { Respectively small } N \\
\text { and insignificant } \\
\text { points dissipation }\end{array}$ \\
\hline 2 & Order-dependent & $P(n)=a_{1} n^{\mathrm{S}}+a_{2} n^{S-1}+a_{3} n^{S-2}+\ldots+a_{S} n+a_{S+1}$ & $\begin{array}{c}\text { Significant } N \text { and in- } \\
\text { significant points } \\
\text { dissipation }\end{array}$ \\
\hline 3 & Logistical & $C_{S R \text { total }}=\frac{1}{N} \int_{0}^{N} P(n) d n ; \quad 0 \leq n \leq N$ & $\begin{array}{c}\text { Significant } N \text { and sig- } \\
\text { nificant points } \\
\text { dissipation }\end{array}$ \\
\hline 4 & $\begin{array}{c}\text { Logarithmic for } \\
2 \text { type }\end{array}$ & $C_{S R \operatorname{logist}}=\frac{1}{N} \int_{0}^{N} \frac{a_{1}}{1+a_{2} e^{-a_{3} n}} ; \quad 0 \leq n \leq N ; a_{2} e^{-a_{3} n} d n ; 0 \leq n \leq N$ & $\begin{array}{c}\text { Dissipation with clear- } \\
\text { ly specified zones }\end{array}$ \\
\hline 5 & $\begin{array}{c}\text { Logarithmic for } \\
3 \text { type }\end{array}$ & $C_{S R 2 \log }=-\sum_{i=n^{*}}^{n^{* *}} \log _{2} P(i)$ & $\begin{array}{c}\text { Dissipation with clear- } \\
\text { ly specified zones }\end{array}$ \\
\hline 6 & $\begin{array}{c}\text { Logarithmic for } \\
4 \text { type }\end{array}$ & $C_{S R 3 \log }=\log _{2}\left(n^{*}-1\right)$ & $\begin{array}{c}\text { Dissipation with } \\
\text { clearly specified zones }\end{array}$ \\
\hline 7 & Enthropic & $C_{S R 4 \log }=-\log _{2}\left(n^{*}-1\right) \cdot \sum_{i=n^{*}}^{n^{* *}} \log _{2} P(i)$ & $\begin{array}{c}\text { Points significant } \\
\text { dissipation }\end{array}$ \\
\hline
\end{tabular}

The table legend: $s$ - order index, $a_{i}$ - coefficients, $n^{*}$ i $n^{* *}$ - conventional zone limits, where the system having a given elements' faults set maintains the operability with probability above zero $P(n)$.

Therefore, to obtain $C_{S R}$, value, we must perform a statistically substantiated experimental series with structurally similar systems under analogical load conditions.

The informational structural statistic model (ISSM) provides opportunity for real-time statistic experiment, removing at every subsequent stage one model structure element with calculation the parameter by the statistic mean value of faultless operations probability [8]. In such a case the structural damage takes place at the model level.

Results. As a result, the proposed information statistical model takes into account and implements two principally different structural damages that allows representing all complex system's damages as some condition diagram (Fig. 1):

- Real predictable damage, reflecting the structural damage at life cycle operational stage, socalled damage at the macro level (Fig. 1,a);

- Virtual damage that will never happen with the object, but are used at ISSM to determine its resiliency so-called damage at the micro level (Fig. 1, $b$ ).

At Fig. 1, b, the top of each diagram indicate the object's performance impairment at the macro level and the lower part refers to the virtual "final breach" of the object's structure at the micro level within frame of the object's actual state fault tolerance express-evaluation methods, i.e. changing the physical objects structure at macro level necessary is to change the corresponding initial ISSM structural state at the micro level. 
Thus, the information model not only serves to determine expected fault tolerance of not yet existing object by its structure (for example, at design phase), thus providing the possibility to compare selected design options by relevant calculated indicators $C_{S R}$, but it can be used to predict these facilities' future operation (1...8, Fig. 2). Time $\tau$, used to represent results in the model (Fig. 2), correlates to the notion of complex system exploitation resource, rather than to the $t$, standard time MTBF.

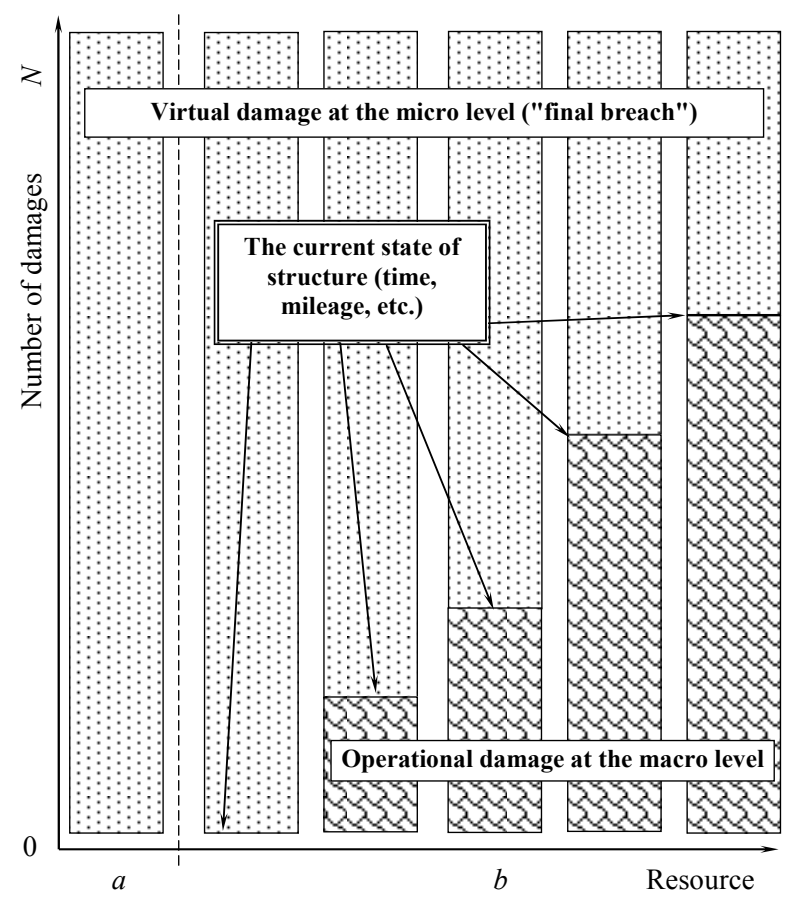

Fig. 1. Diagrams of complex system states during the prognosticated (a) and operational (b) life cycle stages

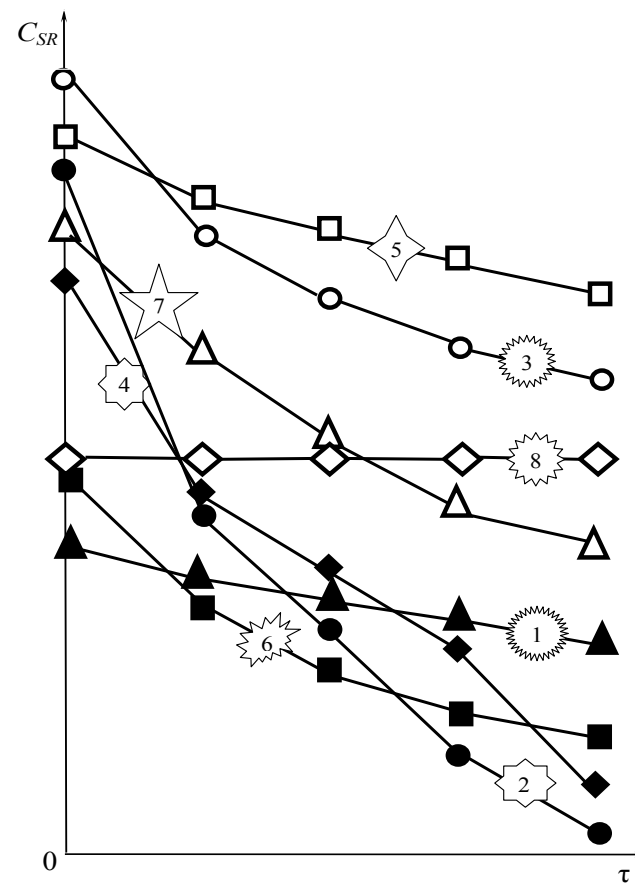

Fig. 2. Example of $C_{S R}$ value application at prognostics of complex systems' states with the use of morphologic models

Conclusions. As a result, reducing the multidimensional criteria space of complex systems' analysis and synthesis to the one-dimensional one proposed are the real-time computed indicators of structural resiliency for complex systems with redundant load: the additive indicator, logistical, logarithmic, order-dependent indicator and entropy-estimating one obtained with the auxiliary of an information morphological model. On the proposed method basis it is possible to compare the structures of functionally similar but structurally different object variances considering the proposed object structure versions and the object's regular load.

At the issue of experimental series (in-situ at the Odessa construction materials plant) testing the proposed information system of decision support at the structural design stage (manufacturing of steel bars for concrete products) we found that this system implementation has 1,7-folds reduced the project works scheduled timing and 1,2-folds reduced the metal products material input without products quality deterioration.

\section{Література}

1. Кочкаров, А.А. Обеспечение стойкости сложных систем. Структурные аспекты [Электронный ресурс] / А.А. Кочкаров, Г.Г. Малинецкий // ИПМ им. М.В. Келдыша РАН. - М., 2005. - Pежим доступа: http://www.keldysh.ru/papers/2005/prep53/prep2005_53.html (Дата звернення: 30.08.2014).

2. Краснянский, М.Н. Надежность функционирования процессов и аппаратов многоассортиментных химических производств: монография / М.Н. Краснянский. — М.: Машиностроение, 2010. — 115 с. 
3. Норенков, И.П. Основы автоматизированного проектирования / И.П. Норенков - 2-е изд., перераб. и доп. - М.: Изд-во МГТУ им. Н.Э. Баумана, 2002. - 334 с

4. Куюнджич, С.М. Разработка и анализ моделей надежности и безопасности систем: монография / С.М. Куюнджич. - М.: Физматлит, 2001. - 463 с.

5. Котенко, Н.А. Морфологические модели надежности энергетического оборудования / Н.А. Котенко, Г.А. Оборский, О.С. Савельева // Моделювання та інформаційні технології. 2010. - Вип. 58. - С. $70-75$.

6. Скворцов, М.С. Решение задачи оптимизации надежности с помощью метода логиковероятностных вкладов / М.С. Скворцов // Надежность. - 2009. - № 2(29). - С. 15 - 29.

7. Савельева, О.С. Экспресс-модель надежности сложных систем в САПР / О.С. Савельева // Пр. Одес. політехн. ун-ту. - 2011. - Вип. 2(36). - С. $174-177$.

8. Савельева, О.С. Критерии отказоустойчивости технических систем / О.С. Савельева // Пр. Одес. політехн.о ун-ту. - 2008. - Вип. 1(29). - С. 12 - 15.

\section{References}

1. Kochkarov, A.A. and Malinetski, G.G. (2005). Providing of Complex Systems Durability. Structural Aspects. Retrieved from http://www.keldysh.ru/papers/2005/prep53/prep2005_53.html

2. Krasnyansky, M.N (2010). The Operational Reliability of Processes and Devices of Multi-Assortment Chemical Production. Moscow: Mashinostroenie.

3. Norenkov, I.P. (2002). Fundamentals of Computer-Aided Design. Moscow: Bauman MSTU Pub. House.

4. Kuyundzhich, S.M. (2001). Development and Analysis of Models of Systems Reliability and Safety. Moscow: Fizmatlit.

5. Kotenko, N.A., Oborsky, G.A. and Savelyeva, O.S. (2010). Morphological models of reliability of power generating equipment. Simulation and Informational Technologies, 58, 70-75.

6. Skvortsov, M.S. (2009). Reliability optimization based on logic-probabilistic contributions method. Dependability, 2, 15-29.

7. Savelyeva, O.S. (2011). Express-model of reliability of complex systems with backing-up in CADD. Odes'kyi Politechnichnyi Universytet. Pratsi, 2, 174-178.

8. Saveleva, O.S. (2008). The criteria of technical systems fault tolerance. Odes'kyi Politechnichnyi Universytet. Pratsi, 1, 12-15.

\section{AHОТАЦІЯ / АННОТАЦИЯ / ABSTRACT}

О.С. Савєльєва, О.М. Красножсн, О.Ю. Лебедєва. Застосування показника структурної відмовостійкості в задачах проектування. Розглянуто питання підвищення ефективності процесу проектування та забезпечення підтримки прийняття рішень на етапі проектування. Зокрема, за умови неоднорідності і неповноти початкової інформації про характеристики елементної бази об'єкта проектування пропонується використовувати його інформаційну структурну статистичну модель. Завдяки морфологічній подібності до об'єкта моделювання вона дозволяє аналізувати його структурну надійність шляхом оцінювання ймовірності безвідмовної роботи. Пропонується на вибір декілька варіантів визначення виду функції надійності в залежності від потужності множини розсіювання статистичної вибірки та варіантів обрахування показника структурної відмовостійкості. Запропонована інформаційна структурна статистична модель дозволяє провести статистичний експеримент в режимі реального часу, видаляючи на кожному наступному кроці по одному елементу із структури моделі, і розрахувати показник за середньостатистичною величиною ймовірності безвідмовної роботи.

Ключові слова: надійність, складні системи, показник структурної відмовостійкості, пошкодження.

О.С. Савельева, А.Н. Красножон, Е.Ю. Лебедева. Использование показателя структурной отказоустойчивости в задачах проектирования. Рассмотрены вопросы повышения эффективности процесса проектирования и обеспечения поддержки принятия решений на этапе проектирования. В частности, при неоднородности и неполноте исходной информации о характеристиках элементной базы объекта проектирования предлагается использовать его информационную структурную статистическую модель. Благодаря морфологическому подобию объекта моделирования она позволяет анализировать его структурную надежность путем оценивания вероятности безотказной работы. Предлагается на выбор несколько вариантов определения вида функции надежности в зависимости от мощности множества рассеяния статистической выборки и вариантов расчета показателя структурной отказоустойчивости. Предложенная информационная структурная статистическая модель позволяет провести статистический эксперимент в режиме реального времени, удаляя на каждом следующем шаге по одному элементу из структуры модели, и рассчитать показатель по среднестатистической величине вероятности безотказной работы.

Ключевые слова: надежность, сложные системы, показатель структурной отказоустойчивости, повреждения. 
O.S. Savelyeva, O.M. Krasnozhon, O.U. Lebedeva. Using the structural fault-tolerance index in project designing. The problems of improving the efficiency of the design process and decision-making processes support at the design stage are considered. In particular, proposed is to use an information structural statistical model under conditions of heterogeneity and incompleteness of the initial data about the design object elementary basis characteristics. Due to the modeling object's morphological similarity it allows to analyze the object's structural reliability by estimating the failure-free operation probabilities. Proposed are several variances to define the reliability function type depending on the statistical sampling set scattering power and options of structural resiliency index calculation. The proposed structural information statistical model allows to conduct the real-time statistical experiment removing at each step one element of the model structure. It also allows to calculate the probability of failure-free operation index on the average value.

Keywords: reliability, complex systems, structural resiliency index, damage.

Reviewer Dr. techn. sciences, Prof. Odesa nat. polytechnic univ. Stanovsky O.L. 